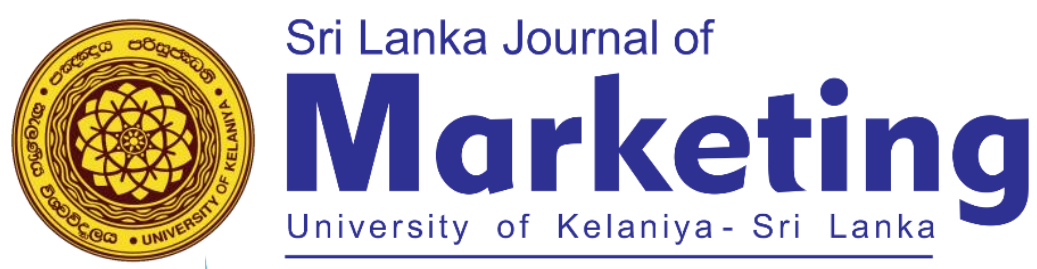

\title{
Factors Influencing Milk Powder Brand Preference: A Case from Kegalle District of Sri Lanka
}

\author{
A.G.K. Wijesinghe \\ Senior Lecturer, Wayamba University of Sri Lanka \\ kusum_wijesinghe06@yahoo.com \\ N.R. Abeynayake \\ Professor, Wayamba University of Sri Lanka \\ rabeynayake@hotmail.com \\ R.L.C. Priyadarshani \\ Undergraduate, Wayamba University of Sri Lanka
}

\section{ABSTRACT}

Recent information released through the mass media related to contamination of imported milk powder with hazardous components has made a considerable effect on the preference of milk powder brands among the consumers in Sri Lanka. This study was focused to investigate: (1) the factors influencing consumer brand preference for local and imported milk powder brands, (2) whether these identified factors have significant influences on consumer preference in milk powder brands. A questionnaire survey was conducted by means of face to face interview to gather primary data from a sample of 250 respondents covering five Divisional Secretariats in Kegalle District. Data were analyzed by using confirmatory factor analysis in AMOS in SPSS. The study shows that trust on the brand, product factors and brand loyalty are the main factors that significant and highly influence consumer brand preference for a particular milk powder brand. Findings of this study are important to milk brand producers, investors, policymakers, marketers, relevant enterprises and government to implement necessary product improvements and quality enhancement in the milk powder industry.

Keywords: Brand Loyalty, Brand preference, Certification, Consumer, Milk powder, Product factor, Trust on brand. 


\section{INTRODUCTION:}

Brand preference is a rational and irrational aspects of consumer behavior. When consider the consumption of dairy products in Sri Lanka, particularly powder milk, it has experienced a substantial growth over the last few decades. Average monthly household expenditure share on milk and milk products in 2018 was $8.2 \%$, ranking fourth in food expenditure (Economic and social statistics of Sri Lanka, 2018). As such, it is evident that milk powder has become an essential food item among consumers in Sri Lanka.

After the conflicting social opinions of powder milk contaminated with components like melamine and dicyandiamide (DCD), consumers more concern in purchasing imported milk powder brands especially for their infants and children. Sri Lankan milk powder market is led by a few reputed imported brands and two main local brands. Local production of spray dried milk powder is insufficient to fulfill the requirement in the country. So, there is a high demand for imported milk powder in the local market. At present, other than the available local milk powder brands new brands are being introduced frequently. Therefore, in Sri Lankan context there is a huge competition within the milk powder industry.

Brand choice basically indicates the consumer's selection of a particular brand. It reflects an exact brand's first preference or demand over the competitors' brands (Khan et al., 2013). There are several factors that influence consumer preference for a particular milk brand and choice of that brand. Researchers found that quality of the product, packaging, price, availability and advertisements are the key factors that influence the preference for branded milk and affect the consumption pattern of the consumer (Sankar \& Sivanesan, 2013; Kumar et al., 2014).

Elangova \& Gomatheeswaran (2015) found that people preferred retail outlets for purchasing branded milk and milk products and most of the respondents have been influenced for the purchase of a particular milk brand by family members. Niezurawaski (2006) has elaborated that availability influence consumer purchasing behavior. Further a research has mentioned that marketing promotions positively effect on consumer purchasing behavior (Fuller et al., 2006). However, consumers prefer a particular brand which is much affordable to them. Therefore, it is timely important to research further the factors influence on milk powder brand selection among consumers in Sri Lanka especially after the social storm of contaminated powder milk. It is also interesting to study which milk powder brand is the most used by the consumers in the Sri Lankan market. In this light, current research was focused to investigate; how consumers' demographic factors, brand loyalty, advertising, brand availability, trust on the brand, price, product factors and subjective norms determine consumer's milk powder brand preference for local and imported milk brands and also, to determine the consumers' highest preferred milk brand in the Sri Lankan market. These findings will be helpful for milk brand producers, investors, 
policymakers, marketers and government to implement necessary product improvements and quality enhancement in the milk powder industry in Sri Lanka. And also, necessary practices that should be incorporated to local milk brand productions to increase the demand by consumers can be proposed.

\section{LITERATURE REVIEW:}

\subsection{Overview of the Milk Powder Consumption in Sri Lanka:}

Sri Lanka is a country which is not self-sufficient in powdered milk production, hence has to heavily depend on imports from countries like Australia and New Zeeland. Sixty-nine thousand metric tons of powdered milk have been imported from foreign countries to fulfill the consumption within the country (Central Bank of Sri Lanka, 2014). According to the recent information hundred thousand metric tons of powdered milk have been imported to the country (Anon, 2020). Local dairy producers in Sri Lanka only provide $40 \%$ of the required amount of powder milk (Economic and Social Statistics, Sri Lanka, 2018). Raw milk consumption by consumers in Sri Lanka has been replaced with powder milk since many years due to convenience and keeping quality.

Attention on food quality and food safety measures regarding imported milk powder products has been increased in recent years due to the risk of diseases caused by additives and issues of production processes. Especially a series of health issues originated in China due to the imported powder milk consumption has generated a considerable attention on the food safety attributes of imported milk products (Anon, 2013). Sri Lankan consumers mostly consider the quality attributes while purchasing imported and local milk powder compared to the consumption of other dairy products (Saheeka et al., 2013). Further, researchers have mentioned that, after the controversial issues of imported milk powder, Sri Lankan consumers' trend to select local milk powder free from additives has been increased (Herath et al., 2015).

\subsection{Theoretical Development for the Research:}

Theory of Reasoned Action Behavior (TRA) explains subjective norm and person's attitude towards the behavior that affect behavioral intension of a person (Ha, 1998). On the other hand, Theory of Planned Behavior (TPB) explains that person's behavioral intention depends on perceived behavioral control and the above-mentioned factors in TRA (Ajzen, 1991).

TPB recognizes consumer behavioral intention and it is assumed that based on the available information to people, they attempt to build rational decisions. This assumption is used to build up ultimate results of consumer behavioral intention and the actual behavior (Ajzen, 1991; Teng \& Wang, 2015).

Consumer Decision Model (CDM) explains the key elements of product choice behavior i.e., brand recognition, information sources, attitude, confidence, purchase intention, and purchase actions 
(Howard, 1989). According to Gifford \& Bernard (2006), brand recognition is much more important to the consumers to assure product quality before purchasing. CDM emphasizes the effects of messages from various information sources for buyers to the brand recognition. The buyer's longing to purchase a product is increased when confidence and attitude are produced. When the desire comes to a certain level, consumers are more likely to buy the product. Numerous studies have been conducted by using $\mathrm{CDM}$ and they have indicated that consumer recognition and confidence can be enhanced by improved production information (Demeritt, 2002; Pieniak et al., 2010). Several researchers have identified factors influence consumers' choice of milk brands and such factors are classified into three broad categories namely: organizations' marketing stimuli, consumer's specific factors and environmental factors (Schmitt, 2009; Kotler, 2005; Schiffman \& Kanuk, 2009).

Consumer purchasing behavior is a dynamic phenomenon and heavily depends on psychological and social aspects of consumers (Soloman et al., 2006). The primary objective of the consumer purchase decision research is to understand the expected attributes of consumers at purchase decisions. A research has mentioned product factors such as taste, smell color and thickness influence purchase decisions of different consumers (Kumar, 2014). Sankar and Sivanesan (2013) found that price is another factor that affects the preference for branded milk and it affects the purchasing behavior of the consumer. Researchers have mentioned that price of a milk product determines how much purchase and consumed (Gilaninia et al., 2013; Schiffman \& Kanuk, 2009). Further, a research has mentioned that consumers who are brand loyal tend to delay purchasing until it is available (Sherratt, 2012). Some studies have mentioned that product promotions contribute positively towards consumers' brand selection (Fuller et al., 2006; Tuan et al., 2013). A research has mentioned that information via mass media communications can influence consumers to buy the product (Kurajdova \& Petrovicova, 2015; Mackenzie, 2004). Based on these, the following four hypotheses are proposed:

- H1. Product factor will influence consumer brand preference for imported and local powder milk.

- H2. Price of the milk brand will influence consumer brand preference for imported and local powder milk.

- H3. Availability of milk powder brand will positively influence on consumer brand preference for imported and local powder milk.

- H4. Advertising will influence consumer brand preference for imported and local powder milk.

\subsection{Effects of Subjective Norm on Consumer Brand Preference:}

Teng and Wang (2015) have defined subjective norm as the degree of social pressure from family members, friends, news and other significant factors for a consumer to accept or reject the purchasing. Elangova and Gomatheeswaran (2015) found that people preferred retail outlets for purchasing branded 
milk and most of the respondents had been influenced for purchasing a particular milk brand by family members. Further, a study has mentioned that dairy product consumption can be increased through the opinions given by family members and friends (Boniface \& Umberger, 2012). Based on that the following hypothesis is proposed:

H5. Subjective norm will influence consumer brand preference for imported and local powder milk.

\subsection{Effect of brand loyalty on consumer brand preference}

Brand loyalty is defined as how strong a customer's preference towards a brand comparing to similar options available in the market. This is often determined based on price volatility or repeat purchase behavior (Anaetemfiok, 2015). When customers have a high relative attitude toward the brand, the actual brand loyalty exists and repurchase behavior is shown. This kind of loyalty is a great asset for a firm (Ebrahim et al., 2016; Reichheld \& Sasser, 1990). Based on that the following hypothesis is proposed:

H6. Brand loyalty will influence consumer brand preference for imported and local powder milk.

\subsection{Effects of Trust on Consumer Brand Preference:}

Building trust among consumers is more important in every food product. Trust is one of the most effective tools to enhance purchase intention while reducing uncertain (Zarantonello \& Schmitt, 2010). Consumers assesses quality and express trustiness about different dairy products prior to purchase (Lakmini \& Abeynayake, 2016). Based on that, following hypothesis is developed:

H7. Trust towards the brand will influence consumer brand preference for imported and local powder milk.

\subsection{Effects of certification on consumer brand preference:}

There was a controversy related to the milk powder certification issued by Sri Lanka Standards Institution (SLSI) to a particular brand of powdered milk recently. As their views, two essential analyses should be carried out in issuing quality and safety certificates by reputed bodies. The first is to test the food product based on the internationally accepted standards and the other is locally established standards (SLS) related to quality and safety. An SLSI certification signifies that a product is manufactured in compliance with SLS specifications, and can be consumed with an assurance of quality (http://www.ft.lk/business/SLSI-confirms- standards-for-milk-powder). Based on these recent trends in the milk powder industry, the following hypothesis is proposed:

H8. Certification of the milk brand will influence consumer preference for imported and local powder milk. 


\section{METHODOLOGY:}

\subsection{Conceptual Framework:}

The proposed conceptual framework (Figure 1) explains the relationship between selected eight Constructs i.e. product factors, price of the brand, brand availability, advertising influence, subjective norms, brand loyalty, trust on brand and certification with consumer brand preference.

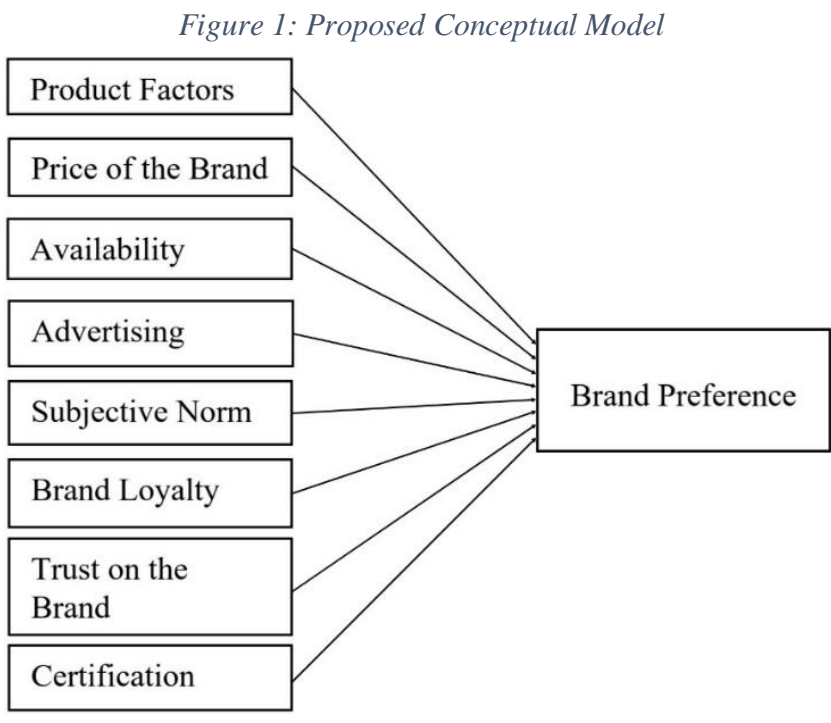

\subsection{Data Collection:}

A survey was conducted to gather primary data by using structured questionnaire from the study population. Questionnaire was pre-tested with a small size of twenty of potential consumers and minor amendments were done to the preliminary questionnaire. Data were collected from 250 consumers selected from supermarkets and retail shops based on systematic sampling by interviewing each third consumer arrived to the super market or retail shop. Sample size was determined based on the Cochran Formula (Cochran, 1963) with 95\% confidence and 6\% error margin. The supermarkets and retail shops were selected randomly from the Divisional Secretariat divisions in Kegalle district which were selected based on multistage sampling method presented in the Figure 2. 


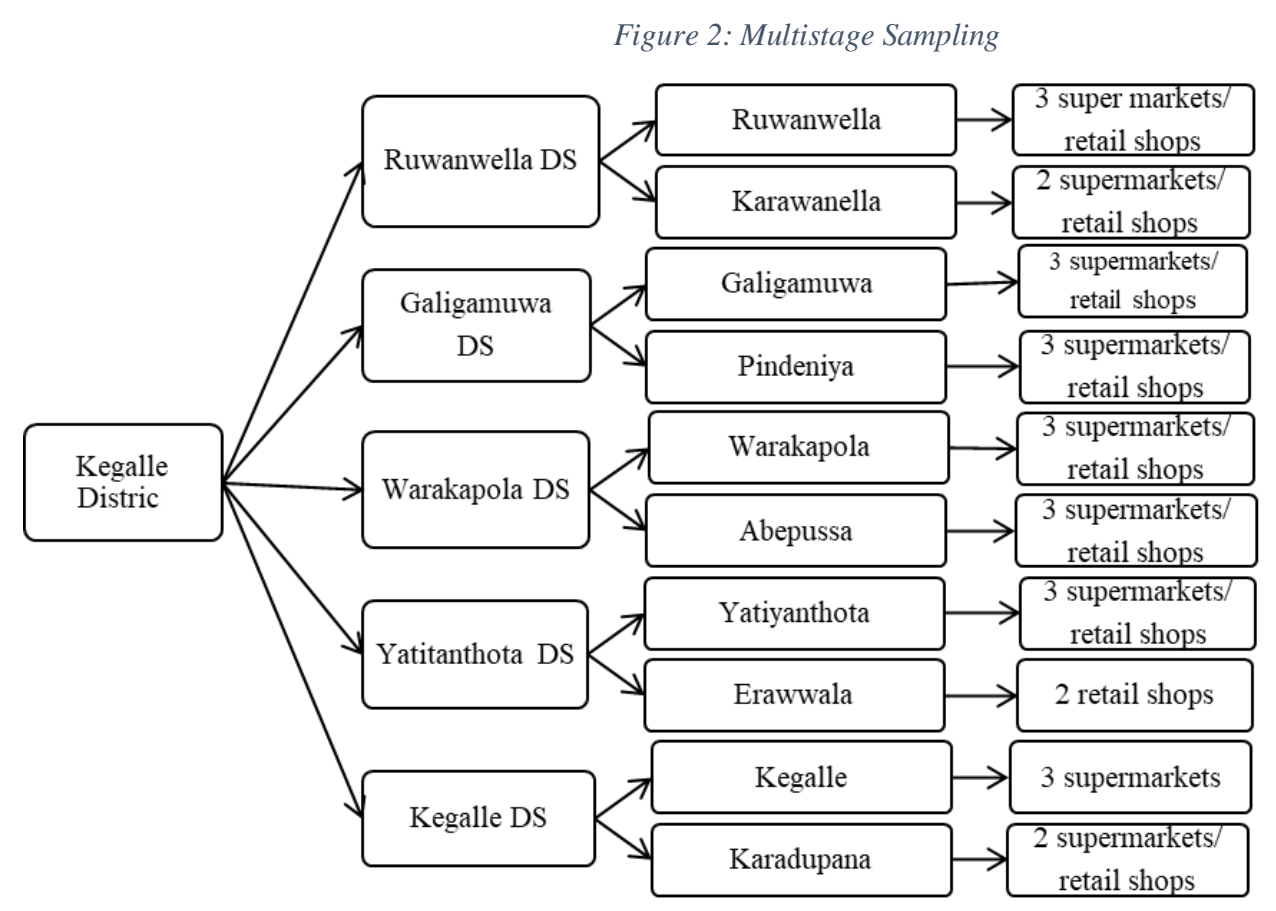

\subsection{Measures:}

The questionnaire was consisted with personal information of the consumer, eight measurement Constructs (Table 1) i.e. brand loyalty (BL), advertising (AD), brand availability (BA), trust on the brand $(\mathrm{TB})$, price of the brand $(\mathrm{PB})$, product factors $(\mathrm{PF})$, certification $(\mathrm{CE})$ and subjective norm $(\mathrm{SN})$. Further, consumer brand preference was measured as dependent variable. Thirty-two items were used to measure these eight Constructs and brand preference. All items were evaluated using a 5-point Likerttype scale, ranging from 1 to 5, where 1 represented "strongly disagree", and 5 represented "strongly agree".

Table 1: Likert Scale Items which are reflected by the Underlying Construct

\begin{tabular}{|c|c|l|}
\hline \multirow{2}{*}{ Construct } & $\begin{array}{c}\text { Item } \\
\text { name }\end{array}$ & \multicolumn{1}{c|}{ Traits assessed from items } \\
\hline \multirow{4}{*}{ Brand Preference (BP) } & BP_I & $\begin{array}{l}\text { Brand name has a significant influence on my purchase } \\
\text { decision }\end{array}$ \\
\cline { 2 - 4 } & BP_II & I use to buy my preferred brand among all others at the shop \\
\cline { 2 - 4 } & BP_III & $\begin{array}{l}\text { Brand name is very important to define my choice of milk } \\
\text { powder }\end{array}$ \\
\cline { 2 - 4 } & BP_IV & I use a particular milk powder brand always \\
\cline { 2 - 4 } & BP_V & I find my preferred milk brand from any available place \\
\hline \multirow{2}{*}{ Brand loyalty (BL) } & BL_I & I like to recommend the milk brand what I use for others \\
\cline { 2 - 4 } & BL_II & $\begin{array}{l}\text { Even though there are good reasons to use another yet I prefer } \\
\text { my milk brand }\end{array}$ \\
\hline \multirow{2}{*}{ Advertising (AD) } & AD_I & $\begin{array}{l}\text { Advertising influence on my purchase decision of milk powder } \\
\text { brand }\end{array}$ \\
\hline
\end{tabular}




\begin{tabular}{|c|c|c|}
\hline & AD_II & $\begin{array}{l}\text { Attractiveness of the advertisements influence on my milk } \\
\text { powder brand choice }\end{array}$ \\
\hline & AD_III & $\begin{array}{l}\text { Celebrity character of the advertisement influence me to } \\
\text { purchase a particular milk powder brand }\end{array}$ \\
\hline & AD_IV & $\begin{array}{l}\text { Opinion Leaders (professionals) influence on my purchase } \\
\text { decision of milk powder brand }\end{array}$ \\
\hline & AV_I & $\begin{array}{l}\text { Availability of the milk powder brand has a significant } \\
\text { influence on my purchase decision }\end{array}$ \\
\hline Brand Availability (AV) & AV_II & $\begin{array}{l}\text { If the brand I preferred is not available, I visit another place to } \\
\text { buy that brand }\end{array}$ \\
\hline & AV_III & If preferred brand is not available, I don't buy any other brand \\
\hline & PB_I & Price make a significant influence on my brand preference \\
\hline Price of hrand (PR) & PB_II & $\begin{array}{l}\text { Even though my preferred milk powder brand has high price, I } \\
\text { buy it }\end{array}$ \\
\hline Filce (ID) & PB_III & $\begin{array}{l}\text { Low price of the local milk powder brands influences me to } \\
\text { purchase }\end{array}$ \\
\hline & PB_IV & If price is low, I prefer to buy it \\
\hline & TB_I & $\begin{array}{l}\text { I believe that my preference brand gives best quality when } \\
\text { compere to another competitor }\end{array}$ \\
\hline & TB_II & I feel it is healthier and provides all the nutrients \\
\hline Trust on brand (TB) & TB_III & $\begin{array}{l}\text { I believe my milk powder brand do not contain harmful } \\
\text { chemicals }\end{array}$ \\
\hline & TB_IV & I believe my milk powder brand do not contain animal fat \\
\hline & TB_V & I trust on the process of milk powder processing \\
\hline & PF_I & $\begin{array}{l}\text { Creamy taste of the milk powder has a significant influence on } \\
\text { my brand preference }\end{array}$ \\
\hline Product Factor (PF) & PF_II & $\begin{array}{l}\text { Quality of the milk powder brand has a significant influence on } \\
\text { my brand preference }\end{array}$ \\
\hline & PF_III & $\begin{array}{l}\text { Design and type of package has a significant influence on my } \\
\text { brand preference }\end{array}$ \\
\hline & CE_I & $\begin{array}{l}\text { Certification of the milk powder brand has a significant } \\
\text { influence on my brand preference }\end{array}$ \\
\hline Certification (CE) & CE_II & $\begin{array}{l}\text { I consider the certification of the milk brand before making the } \\
\text { purchase decision (SLS \& ISO) }\end{array}$ \\
\hline & CE_III & I buy only certified milk powder brands among all others \\
\hline & SN_I & My family think I should buy this brand \\
\hline Subiective norm (SN) & SN_II & My friends think I should buy this brand \\
\hline 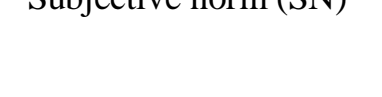 & SN_III & $\begin{array}{l}\text { Newspaper, magazines and information sources affect my } \\
\text { purchase decision of my milk powder brand }\end{array}$ \\
\hline
\end{tabular}

\subsection{Data Analysis:}

The Kaiser-Meyer-Olkin (KMO) test was proceeded to check the sampling adequacy for the multivariate analysis while Pearson Correlation Coefficient was employed to ensure that the multivariate analysis was not distorted (Rohlf, 2009). Descriptive statistics were used to analyze the 
demographic factors and consumer preference for selected local and imported milk powder brands. Internal consistency of each construct was examined by using Cronbach's Alpha Reliability Coefficient. The validity of the measurement model was measured using Confirmatory Factor Analysis (CFA). Structural Equation Modeling (SEM) was used to examine the proposed model by using Analysis of Moment Structure (AMOS) in SPSS 24 version and estimates were done based on maximum likelihood estimation technique.

\section{RESULTS AND DISCUSSION:}

\subsection{Descriptive Statistics of the Sample:}

Majority of the respondents were women (54\%) and $46 \%$ were men in the studied population (Table 2). Population contained $45 \%$ and $25 \%$ in the age group of $30-49$ and above 50 respectively. Among the sample population, $36 \%$ of the respondents had educated up to primary level and majority of the respondents had secondary level education (48\%). Number of respondents up to tertiary level education is $16 \%$. In the population, $65 \%$ were employed and $69 \%$ represented above LKR 35,000 income level.

\subsection{Descriptive Statistics of Consumer Brand Preference:}

Twenty-five percent (25\%) of respondents preferred to purchase only imported milk powder brands and $24 \%$ of respondents preferred to purchase only local milk powder brands, whereas, majority of the respondents (51\%) preferred to purchase both local and imported milk powder without considering the origin of the product.

Table 2: Socio-demographic Characteristics of the Sample

\begin{tabular}{|l|l|c|}
\hline \multicolumn{1}{|c|}{ Parameter } & \multicolumn{1}{|c|}{ Category } & Percentage (\%) \\
\hline Gender & Male & 46 \\
\hline & Female & 54 \\
\hline Age & $15-29$ years & 30 \\
\hline & $30-49$ years & 45 \\
\hline & 50 and above & 25 \\
\hline Employment Status & Unemployed & 35 \\
\hline & Employed & 65 \\
\hline Monthly Income & Less than 15,000 & 6 \\
\hline & $15,000-34,999$ & 33 \\
\hline & $35,000-59,999$ & 39 \\
\hline & Above 59,000 & 22 \\
\hline Educational Level & Primary & 46 \\
\hline & Secondary & 16 \\
\hline & Tertiary & 48 \\
\hline
\end{tabular}

Source: Survey Data 


\subsection{Sampling Adequacy:}

Kaiser-Meyer-Olkin (KMO) and Bartlett's Test of Sphericity (BTS) were carried out to confirm the factorability of data. The recommended threshold value for KMO is at least 0.60 and BTS must be significant at $\mathrm{p}<0.1$. The results of the both tests were found to meet the minimum requirements (Table $3)$.

Table 3: KMO and Bartlett's Test

\begin{tabular}{|l|l|}
\hline Kaiser-Meyer-Olkin Measure of Sampling Adequacy & .734 \\
\hline Bartlett's Test of Sphericity Approx. Chi-Square & 2602.804 \\
\hline df & 351 \\
\hline Probability & .000 \\
\hline
\end{tabular}

\subsection{Reliability Statistics:}

Cronbach's Alpha is the most common tool to measure internal consistency. It is acceptable when Cronbach's alpha is higher than 0.7 (Hair et al., 1998). Internal consistency of all Constructs showed higher than 0.7 which indicated that internal consistencies of items within the Constructs are acceptable.

Confirmatory Factor Analysis validated the proposed model showing higher factor loadings (greater than 0.5 ) of items within the Construct and measurement model explained $66.94 \%$ of the total variance. Variance contribution from each construct is given in Table 4.

Table 4:Total Variance Explained by the Constructs

\begin{tabular}{|c|c|c|}
\hline \multirow{2}{*}{ Construct } & \multicolumn{2}{|c|}{ Rotation Sums of Squared Loadings } \\
\cline { 2 - 3 } & \% of Variance & Cumulative \% \\
\hline TB & 10.449 & 10.449 \\
\hline PB & 8.900 & 19.348 \\
\hline AD & 8.779 & 28.128 \\
\hline PF & 8.423 & 36.551 \\
\hline AV & 8.230 & 44.782 \\
\hline SN & 8.056 & 52.837 \\
\hline CE & 7.858 & 60.695 \\
\hline BL & 6.242 & 66.937 \\
\hline
\end{tabular}

Source: Survey Data

\subsection{Assessment of Fitness for the Structural Model:}

The measurement model elaborated good model appropriateness with the data having $\chi 2=1111.149$, degree of freedom $(\mathrm{df})=456, \mathrm{p}$-value $=0.000$, root mean square error approximation $($ RMSEA $)=$ 0.063 , Tucker-Lewis index $(\mathrm{TLI})=0.88$, Normed fit index $(\mathrm{NFI})=0.92$, comparative fit index $(\mathrm{CFI})=$ 0.90 , goodness of fit index $(\mathrm{GFI})=0.91$, Adjusted goodness of fit index $(\mathrm{AGFI})=0.89$ and $\mathrm{CMIN} / \mathrm{df}=$ 
2.279. It was revealed that model fit indices passed the adequate threshold level (Byrne, 2016) and hence, it is validated that the measurement components corresponded to their underlying latent construct (Table 5).

Table 5:Goodness of fit Indices

\begin{tabular}{|l|l|l|l|}
\hline \multicolumn{1}{|c|}{ Category } & \multicolumn{1}{c|}{ Indices } & \multicolumn{1}{c|}{ Recommended Least } & \multicolumn{1}{c|}{ Attained Value } \\
\hline \multirow{3}{*}{ Absolute Fit } & $\chi 2$ & $\mathrm{p}<0.05$ & 0.000 \\
\cline { 2 - 4 } & GFI & $\mathrm{p}>0.90$ & 0.91 \\
\cline { 2 - 4 } & RMSEA & $\mathrm{p}<0.08$ & 0.06 \\
\hline Incremental Fit & AGFI & $\mathrm{p}>0.90$ & 0.89 \\
\hline & CFI & $\mathrm{p}>0.90$ & 0.90 \\
\hline & TLI & $\mathrm{p}>0.90$ & 0.88 \\
\hline & NFI & $\mathrm{p}>0.90$ & 0.92 \\
\hline Parsimonious Fit & CMIN/DF & $3-5$ & 2.27 \\
\hline
\end{tabular}

\subsection{Relationship between Constructs and Brand Preference:}

Trust on the brand, product factors (factors related to the product like taste, quality, design of packing etc.) and brand loyalty significantly effect on brand preference according to the structural path estimate of Structural Equation Modelling (Table 6). Hence, hypotheses H7, H1 and H6 are supported by the results. These results confirmed that trust on the brand, product factors and brand loyalty are good predictors of consumer brand preference.

The items that were used to measure the trust on the brand were quality of the brand, healthiness and nutritional value, not contained harmful chemicals, not contained animal fat and trust on the processing method. The items that were used to measure the product factor were "creamy taste of the milk powder, quality of the milk powder brand and design and type of package". The items that were used to measure the brand loyalty were "I like to recommend the milk brand what I use for others" and "even though there are good reasons to use another yet I prefer my milk brand". Therefore, the attributes described by trust on the brand, product factors and brand loyalty should be incorporated to any milk powder brand in order to enhance consumer brand preference.

Table 6: Results of the Structural Equation Modelling: Standardized Path Estimates

\begin{tabular}{|llllll|}
\hline & & & Estimate & S.E. & Prob. \\
\hline BP & $<---$ & AV & -.052 & .065 & .423 \\
BP & $<---$ & CE & .073 & .057 & .204 \\
BP & $<---$ & AD & .087 & .086 & .308 \\
BP & $<---$ & TB & .775 & .228 & $* * *$ \\
BP & $<---$ & PB & .069 & .098 & .482 \\
BP & $<---$ & BL & .235 & .079 & .003 \\
BP & $<---$ & SN & -.103 & .086 & .231 \\
BP & $<---$ & PF & .229 & .072 & .001 \\
\hline
\end{tabular}

Source: Survey Data 


\subsection{Regression Weights In between Hypothesized Relationship:}

Trust on the brand, product factors and brand loyalty significantly and positively contribute to the consumer brand preference for local and imported milk powder (Table 6). The results indicate that "trust towards the brand" is the major factor that contributes to consumer brand preference $(0.775)$ at $(* * * \mathrm{P}<0.0001)$ (Table 6). Further the results indicate that product factor is the second major factor contributes to consumer brand preference $(0.229)$ at $(* * * \mathrm{P}<0.001)$. Brand loyalty is the third factor that contributes to consumer brand preference for imported and local milk powder brands $(0.235)$ at $(* * * \mathrm{P}<0.003)$.

The standardized regression weights $(\lambda)$ of 28 items out of 32 items are greater than 0.5 , achieving the recommended threshold level of 0.50 (Figure 3). Thus, 28 items were considered to be significant with regard to their corresponding latent constructs (Hair et al, 2006).

\section{Figure 3: Structural Model}

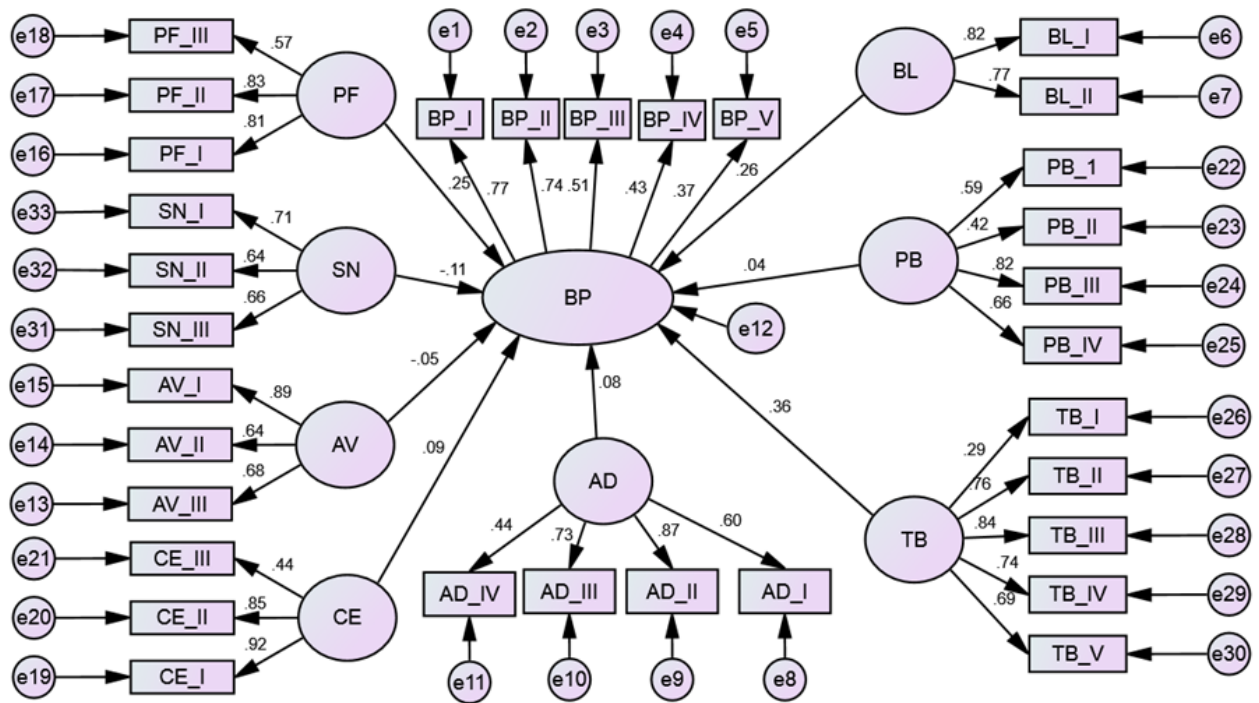

BL-brand loyalty, AD-advertising effect, BA-brand availability, TB-trust on the brand, PB-price of the brand, PF-product factor, CE-certification, SN-subjective norms, BP-brand preference

\subsection{Trust on the Brand:}

Results show that the items i.e. belief of "milk powder does not contain harmful chemicals, it is healthy and it provides all the nutrients, and it does not contain animal fat" (TB_III, TB_II and TB_IV) highly contribute to trust towards the milk brand (TB) by $84 \%, 76 \%$ and $74 \%$ respectively. Therefore, if we want to enhance trust towards any milk powder brand, practices reflected by those items should be implemented (Figure 3). 


\subsection{Product Factor:}

The item PF_II which indicates the "quality of the milk powder" shows higher factor loading $(83 \%)$ towards the Construct of product factor (PF). Item PF_I denote the "creamy taste of the milk powder" that makes a factor loading (81\%) towards the product factor (PF) of the milk brand (Figure 3).

\subsection{Brand Loyalty:}

The items BL_I and BL_II contribute towards the brand loyalty (BL) by $82 \%$ and $77 \%$ respectively. Item BL_I denotes "I like to recommend the milk brand what I use for others" and BL_II reflects "even though there are good reasons to use another yet I prefer my milk brand". This shows that consumers in this population are brand loyal. Hence, if we want to enhance the consumer preference towards local milk powder brands, brand loyalty should be created among consumers by implementing expected attributes.

\subsection{Subjective Norm:}

Family influence (SN_I) on the preferred milk brand highly contributes $(71 \%)$ to the Construct denoted as subjective norm (SN). It reflects that "family members' views on milk brand can make significant influence on milk powder brand preference". As well as information given through the sources i.e. newspapers, magazines and others (SN_III) effects on milk powder brand preference (66\%). But subjective norm does not make a significant effect on consumer brand preference. Yet there is a positive effect up to a certain level. Therefore, awareness of family members and providing true information via newspapers and magazines are beneficial to enhance brand preference (Figure 3).

\subsection{Price of the Brand:}

The items PB_III and PB_IV contribute highest factor loadings towards the Construct of price of the brand (PB) showing the values of $82 \%$ and $66 \%$ respectively. Item PB_III indicates "low price of the milk brand" influences to purchase and PB_IV indicates "if price is low prefer to buy it". These findings reflect that low price of any milk powder brand has an influence on the Construct of price of the brand (PB). But price of a brand does not make any significant influence on brand preference. Yet positive effect can be seen. Therefore, if milk producers can keep the prices of their milk brands lower than competitive brands, brand preference can be enhanced.

\subsection{Certification:}

The items of CE_I and CE_II show highest factor loadings towards the Construct of certification (CE) i.e. $92 \%$ and $85 \%$ contributions respectively. CE_I denote that "certification of the milk powder brand influences on brand preference" and CE_II denotes the "certification of the milk brand (SLS and ISO)" 
is considered before making the purchase decision. But certification does not have a significant influence on consumer brand preference, but it shows a certain positive effect. Therefore, certification is beneficial.

\subsection{Brand Availability:}

Also, item AV_I explain that "availability of the milk powder brand has a significant influence on purchase decision of the milk brand" and it contributes $89 \%$ to the Construct "availability (AV)". Item AV_III denotes that "if preferred brand is not available, do not buy any other brand" and it represents $68 \%$ to the Construct "availability (AV)". Even though, the Construct "availability" does not make a significant influence on consumer brand preference, yet make some positive effect. Therefore, producers should pay their attention to increase the availability of their milk brands sufficiently.

\subsection{Advertising:}

The items AD_II and AD_III contribute highest factor loadings towards the Construct of advertising (AD) showing the values of $87 \%$ and $73 \%$ respectively. Item AD_II, denotes that "attractiveness of the advertisements influence milk powder brand choice" and item AD_III denotes "celebrity character of the advertisement influence purchase decision of a particular milk powder brand". Even though the Construct “advertising" doesn't make a significant influence on consumer brand preference but make some positive effect.

\subsection{Significant Covariance between Constructs}

Several significant covariance can be seen among selected Constructs (Table 7). Accordingly, covariance between subjective norms and trust towards the brand, product factors and trust towards the brand, and subjective norms and product factors are important. This covariance is highly significant $(* * * P<0.001)$.

Table 7: Significant Covariance between Constructs

\begin{tabular}{|llllll|}
\hline & & & Estimate & S.E. & P \\
\hline AV & $<-->$ & PF & .243 & .056 & $* * *$ \\
AV & $<-->$ & PB & .130 & .041 & .001 \\
PF & $<-->$ & CE & .124 & .051 & .015 \\
PF & $<-->$ & PB & .201 & .044 & $* * *$ \\
PB & $<-->$ & TB & .094 & .027 & $* * *$ \\
PF & $<-->$ & SN & .215 & .049 & $* * *$ \\
CE & $<-->$ & TB & .072 & .026 & .006 \\
PF & $<-->$ & TB & .103 & .030 & $* * *$ \\
TB & $<-->$ & SN & .077 & .025 & .002 \\
\hline
\end{tabular}

Levels of statistical significance, $* * P<0.01, * * * P<0.001$ 


\section{CONCLUSION:}

Trust on the brand, product factors and brand loyalty are the main factors that significant and highly influence consumer brand preferences for a particular milk powder brand.

\subsection{Trust on the Brand:}

Out of the significant factors, trust is the main factor that contributes to consumer brand preference for a given milk powder brand. The items that were used to measure the trust on the brand were quality of the brand, healthiness and nutritional value, not contained harmful chemicals, not contained animal fat and trust on the processing method. Out of these items, the beliefs of "it does not contain harmful chemicals, it is healthy and it provides all the nutrients, and it does not contain animal fat" contribute highest towards the trust on milk brand. Therefore, maintaining the quality, nutritional values, keeping away from harmful chemicals and harmful animal fat and good practices in processing should be implemented to enhance the consumer preference for any milk brand irrespective to country of origin.

\subsection{Product Factor}

Product factor is the second highest factor that contributes to consumer brand preference. Product factor represents by threeitems i.e. "creamy taste of the milk powder, quality of the milk powder and design and type of packaging". Therefore, these attributes should be incorporated to any milk powder brand in order to enhance consumer brand preference. Out of these three items the belief of "quality of the milk powder" and feeling of "creamy taste of the milk powder" contribute highest towards the product factor of the milk brand. Therefore, producers should pay their attention to develop these attributes in relation to their milk brands.

\subsection{Brand Loyalty:}

Brand loyalty is the third factor that contributes to consumer brand preference. The items that were used to measure the brand loyalty were "I like to recommend the milk brand what I use for others" and "even though there are good reasons to use another yet I prefer my milk brand". Therefore, the consumers in this population are brand loyal. Therefore, enhancing availability of any milk brand is important to maintain brand loyalty among consumers.

There was a controversial issue which recently arisen on imported milk powder brands after the storm of dicyandiamide and melamine. But according to the identified order of the consumer preference for milk powder brands, the first preference goes for an imported milk brand and second and third preferences go for two local brands at 38\%, 25\% and $21 \%$ preferences respectively. Consumers in this population have mentioned that non-availability is the major issue in local milk brands. Hence local milk powder availability should be increased. Other than that local milk brand producers should make 
relevant strategies to maintain good product factors and trust on their brands in order to create brand preference among consumers.

Findings of this study will be helpful for milk producers, investors, policy makers, marketers and government to implement necessary practices to enhance availability of the relevant milk brands and enhance consumer preference by incorporating good practices and expecting attributes by consumers for milk powder productions.

\section{REFERENCES:}

[1]. Ajzen, I. (1991). The theory of Planned Behavior. Organizational Behavior and Human Decision Process.50 (2):179-211, DOI: 10.1016/0749-5978(91)90020T.

[2]. Anaetemfiok, E. S. (2015). Brand Loyalty and Consumption of Dairy Products among International Students in North Cyprus, Master Degree Thesis, Eastern Mediterranean University, Gazimağusa, North Cyprus: online access 02.06.2020.

[3]. Anon, (2020). Government to implement price formula on imported milk, Daily Mirror, (Accessed on 11.05.2020), available at http://www.dailymirror.lk/business-news/Government-to-implement-priceformula-on-imported-milk/273-163926.

[4]. Anon, (2013). China asks importers to recall contaminated Fonterra products. [Accessed on 24th July 2019]. Available at http://www.bloomberg.com/news/articles/2013-08-03/.

[5]. Byrne, B.M. (2016). Structural Equation Modeling with Amos: Basic Concepts, Applications and Programming, (Third ed). Routledge, New York.

[6]. Central Bank Annual Report, (2014). Central Bank of Sri Lanka, Colombo.

[7]. Cochran, W.G. (1963). Sampling Techniques, (2nd Ed.), New York: John Wiley and Sons, Inc.

[8]. Demeritt, L. (2002). All Things Organic: A Look at the Organic Consumer, The Hartman Group, Bellevue (cross reference).

[9]. Ebrahim, R., Ghoneim, A., Irani, Z., \& Fan Ying. (2016). A brand preference and repurchase intention model: the role of consumer experience, Journal of Marketing Management, Vol. 32, Issue 13-14, Online.

[10]. Economic and Social statistics of Sri Lanka, (2018). Central Bank of Sri Lanka.

[11]. Elangovan, N., \& Gomatheeswaran, M. (2015). A study on consumer behavior towards various brands of milk and milk products with special reference to Thudiyalur town at Coimbatore district in Tamil Nadu. International Journal of Multidisciplinary Research and Development, 5, 595 - 601.

[12]. Fuller, F., Beghin, J., \& Rozelle, S. (2006). Consumption of Dairy Products in Urban China: Results from Beijing, Shanghai, and Guangzhou.

[13]. Gifford, K., \& Bernard, J.C. (2006). Influencing consumer purchase likelihood of organic food. International Journal of Consumer Studies, 30, 155-163. 
[14]. Gilaninia, S., Taleghani, M., \& Azizi, N. (2013). Marketing Mix and Consumer Behavior. Arabian Journal of Business and Management Review, 2(12), 53-58.

[15]. Hair, J.F., Anderson, R.E., Tatham, R.L., \& Black, W.C. (1998). Multivariate DataAnalysis, (5th ed.) Prentice Hall, New Jersy.

[16]. Herath, H.M.K.N.B., Jayasinghe-Mudalige, U.K., Lokuge, L.D.M.N., \& Herath L.M.L.K. (2015). Impact of Information Shocks on Consumer Preferences on Food Quality: Case of Milk Powder Products. In Proceedings of $14^{\text {th }}$ Agricultural Research Symposium, Wayamba University of Sri Lanka.417-421.

[17]. Howard, J.A. (1989). Consumer Behaviour in Marketing Strategy. Prentice-Hall,Englewood Cliffs. http://www.ft.lk/business/SLSI-confirms-Anchor-meets-national-standards-for-milk-powder/34-696529, online access 02.06.2020.

[18]. Khan, S., \& Rohi, S. (2013). Investigating the factors affecting youth brand choice for mobile phones purchase - a Study of private universities. Journal of Management and Marketing, 8(2), 369-384.

[19]. Kumar, A., \& Babu, S. (2014). Factors Influencing Consumer Buying Behavior with Special Reference to Dairy Products in Pondicherry State. International Monthly Refereed Journal of Research in Management Technology, 3, 65-73.

[20]. Kurajdova, K., \& Petrovicova, J.T. (2015). Literature review on factors influencing milk purchase behavior, International Review of Management and Marketing, Vol. 5, No. 1, 2015, pp.9-25, ISSN: 2146-4405, www.econjournals.com

[21]. Kotler, P., Wong, V., Saunders, J., \& Armstrong, G. (2005). Principles of Marketing. Harlow: Pearson.

[22]. Lakmali, W.M.T.C., \& Abeynayake N.R. (2016). Dynamics of Consumer Behaviour and Consumer Perception on Fresh Milk Consumption: Case in Kandy District Sri Lanka. In Proceedings of $16^{\text {th }}$ Agricultural Research Symposium, Wayamba University of Sri Lanka. pp. 6-10.

[23]. MacKenzie, I. (2004). A course for Business Studies and Economics students. Cambridge, UK: Cambridge University Press.

[24]. Niezurawski, L. (2006). Determinants of customer satisfaction on the markets of selected dairy products. Polish journal of Food and Nutrition Sciences, 15(56), 155-160.

[25]. Pieniak, Z., Verbeke, W., Olsen, S.O., Birch Hansen, K., \& Brunso, K. (2010). Health related attitudes as a basis for segmenting European food consumers. Food Policy, 35, 448-455.

[26]. Reichheld, F., \& Sasser, W.E. Jr. (1990). Zero defections: quality comes to services, Harvard Business Review, Vol. 68, September/October, pp. 105-11.

[27]. Rohlf, F. J. (2009). NTSYSpc Numerical taxonomy and multivariate analysis system, v. 2.2. Setauket, New York: Exeter Software

[28]. Saheeka, R.F., Udugama, J.M.M., Jayasinghe-Mudalige, U.K., \& Attanayake, A.M.C.M. (2013). Determinants of dairy product consumption patterns: The role of consumer perception on food quality attribute. In Proceedings of 12th Agricultural Research Symposium, Wayamba University of Sri Lanka. 419423. 
[29]. Sankar, S., \& Sivanesan, R. (2013). Brand preference of packed milk -comparative study on rural and urban consumers in Kanyakumari district. International Journal of Business and Management Invention, 2(7), 2335.

[30]. Schiffman, L. G., \& Kanuk, L. L. (2009). Consumer behavior. Englewood Cliffs, NJ: Prentice-Hall.

[31]. Schmitt, B. (2009). The concept of brand experience. Journal of Brand Management, 16, 417-419. doi:10.1057/bm.2009.5, Google Scholar.

[32]. Sherratt, A. (2012). Managing marketing. Chartered Institute of Marketing. London: BPP Learning Media Ltd.

[33]. Solomon, M. R. (c2006). Consumer behavior: buying, having and being. (7th ed.), New Jersey, USA: Pearson Prentice Hall.

[34]. Teng, C., \& Wang, Y. (2015). Decisional factors driving organic food consumption: Generation of consumer purchase intentions. British Food Journal117, 1066-1081.

[35]. Tuan, L., Phuong, N., Ngoc, L., \& Mai, L. (2013). Powdered Milk Consumers’ Buying Behavior. International Journal of Business and Management, 8(2), 29-37.

[36]. Zarantonello, L., \& Schmitt, B. H. (2010). Using the brand experience scale to profile consumers and predict consumer behavior. Journal of Brand Management, 17(7), 532-540. doi:10.1057/bm.2010.4 